\title{
Miniaturowy globus Johannesa Deura z kolekcji Muzeum Uniwersytetu Jagiellońskiego
}

\section{Małgorzata Taborska}

https://orcid.org/0000-0002-9228-4340

Muzeum Uniwersytetu Jagiellońskiego

Zarys treści: Globus autorstwa Johannesa Deura (1667-1734) z Amsterdamu, znajdujący się w kolekcji Muzeum UJ jest egzemplarzem unikatowym. Na świecie zachowały się tylko trzy takie dzieła. Powstał na przełomie wieków XVII i XVIII w Amsterdamie. Jest przykładem globusa kieszonkowego, zaliczanego do miniaturowych. Analizowano stan zachowania obiektu, jego konstrukcję, mapę nieba i mapę Ziemi. Pozwoliło to na zadatowanie obiektu na lata 1699-1707.

Słowa kluczowe: kartografia globusowa, mapa Ziemi, mapa nieba, Jan Heweliusz, Johannes Deur, Amsterdam

\section{Rodzaje globusów i prezentacja tematu}

Za najcenniejsze globusy uznaje się obiekty wykonane do połowy XIX w. Cezura ta, przyjęta przez wiedeńskie towarzystwo Coronelli Society ${ }^{1}$, uzasadniona jest techniką druku. Wprowadzenie litografii usprawniło bowiem produkcję i spowodowało spadek cen. W Polsce takich najcenniejszych globusów zachowało się nie więcej niż sto ${ }^{2}$, w tym miniaturowych jest siedem, w większości rękopiśmiennych ${ }^{3}$. Omawiany obiekt jest prawdopodobnie jedynym globusem kieszonkowym w Polsce.

Kule globusowe mają zróżnicowane średnice, co przekłada się na rozmiary mapy i zasób prezentowanej treści. Dlatego właśnie rozmiar jest najbardziej naturalnym kryterium podziału. Rodzaje podstaw i osadzenie kul są sprawą wtórną. Największe - globusy „biblioteczne” czy też

\footnotetext{
${ }^{1}$ The International Society for the Study of Globes (http://www.coronelli.org/ index_e.html, dostęp: 5 marca 2019).

2 B. Olszewicz, Alte Globen in Polen, ,Der Globusfreund”, 15/16, 1966/1967, s. 263-277.

${ }^{3}$ M. Taborska, Antique globes in Poland, 1480-1860. A new inventory, , Journal of the International Map Collectors' Society", 161, 2020, s. 18-30, 24-25.
}

Abstract: The globe made by Johannes Deur (1667-1734) from Amsterdam, currently in the collection of the JU Museum, is a unique object. Only three works of this kind remain in the world. The object was created at the turn of the eighteenth century in Amsterdam. It is an example of a pocket globe, classified as a miniature globe. The analysis focuses on the object's condition, its design, and the map of the Earth and the sky. The results made it possible to date it to 1699-1707.

Keywords: globe cartography, map of the Earth, map of the sky, Johannes Hevelius, Johannes Deur, Amsterdam

„podłogowe”4, mają kule o średnicy ponad $50 \mathrm{~cm}$. Zwykle ustawiane są bezpośrednio na podłodze, niekiedy na specjalnie dostosowanych podestach. Nieco mniejsze są globusy średnie, „stołowe”, o kulach o średnicy od ok. $20 \mathrm{~cm}$ do $50 \mathrm{~cm}$. Trzecią grupą są małe globusy „biurkowe” lub „szkolne” o średnicach kul od ok. $10 \mathrm{~cm}$ do $20 \mathrm{~cm}$. Najmniejsze rozmiary maja „miniaturowe” o średnicy poniżej $10 \mathrm{~cm}$. Takie kule doskonale mieszczą się w dłoni. W przypadku średnic poniżej $3 \mathrm{~cm}$ mapa jest bardzo uproszczona. Przykładem globusów miniaturowych są globusy kieszonkowe - jak omawiany obiekt.

Najwcześniejsze rękopiśmienne globusy produkowane były jako pojedyncze egzemplarze. Podłożem mógł być metal (mosiądz, miedź, srebro), rzadziej kość słoniowa czy inne materiały. Seryjna produkcja możliwa była dopiero przy zastosowaniu druku, kiedy to papierowe mapy naklejane były na przygotowane kule gipsowe, rzadziej

${ }^{4}$ E. Dekker, Globes at Greenwich. A catalogue of the globes and armillary spheres in the National Martime Museum, Oxford 1999. 
drewniane, z papier mâché czy z samej tektury. W przypadku miniaturowych obiektów stosowano najczęściej drewno lub $p a-$ pier mâché. Segmenty map z rysunkiem czarnych linii były po naklejeniu ręcznie kolorowane. Przed rokiem 1900 globusy kieszonkowe produkowano, stosując mapy drukowane - najczęściej miedziorytnicze lub litograficzne, choć można spotkać i drzeworytnicze czy rękopiśmienne, m.in. srebrne globusy kieszonkowe z National Martime Museum w Greenwich'.

Niewielkie globusy Ziemi produkowane były już w drugiej połowie XVI w. (nieba znane były już w średniowieczu). Najstarszy znany miniaturowy drukowany globus Ziemi ma średnicę $5,3 \mathrm{~cm}$, wydany został przez Willema Janszoona Blaeua (1571-1638) w 1616 r. ${ }^{6}$ Czasem globusy takie miały ciekawe formy podstaw, choćby drewniane etui w postaci okrąłłej szkatułki, od zewnątrz malowanej w ozdobne ornamenty (Jean Fortin) ${ }^{7}$. Zdarzały się również całe komplety obejmujące globus Ziemi, etui z mapą nieba oraz sferę armilarną (Dudley Adams) ${ }^{8}$. Najciekawszym przykładem jest zestaw złożony rozkładanego globusa (śr. $5 \mathrm{~cm}$ ), z wyjmowaną ze środka sferą armilarną (Johann Baptiste Homann) i etui z mapa nieba'. W latach 1830-1859 firma Holbrook Apparatus Manufacturing Co wydała miniaturowe (śr. 7,6 cm) i małe globusy (śr. $12 \mathrm{~cm}$ ), o kulach rozkładanych wzdłuż południka. $\mathrm{Na}$ obu płaszczyznach widocznych po ich rozłożeniu umieszczono planigloby ${ }^{10}$.

\footnotetext{
${ }^{5}$ E. Dekker, Globes at Greenwich, s. 101-103, 203-204, 235.

${ }^{6}$ P. van der Krogt, Old globes in the Netherlands. A catalogue of terrestrial and celestial globes made prior to 1850 and preserved in Dutch collections, Utrecht 1984, s. 53.

${ }^{7}$ E. Dekker, Globes at Greenwich, s. 339-340, fot. 17.

${ }^{8}$ E. Dekker, Pocket globe, w: The History of Cartography, t. 4: Cartography in the European Enlightenment, ed. M.H. Edney, M.S. Pedly, Chicago 2020, s. 573-575.

${ }^{9}$ S. Sumira, Globes: 400 Years of Exploration, Navigation, and Power, Chicago 2014.

${ }^{10}$ Antique Maps, Globes, Books \& Prints by Murray Hudson, 2021, Rare American Holbrook Hinged School Globe. Nr G-10367 (https://antiquemapsandglobes.com/Globe/Antique/Rare-American-Holbrook-Hinged-School-Globe?G=10367, dostęp: 5 stycznia 2021).
}

Miniaturowe globusy to zróżnicowana grupa. W tabeli 1 zestawiono informacje o obiektach wydanych do połowy XIX w. Przedstawia ona najważniejszych wytwórców, nie wyczerpując tematu, bowiem na aukcjach ciągle pojawiają się nowe obiekty. Szczególnie popularne są dzieła dziewiętnastowiecznych wytwórców londyńskich, czasem wykonane w oparciu o tę samą matrycę mapy ${ }^{11}$.

Można wyróżnić sześć wariantów miniaturowych globusów: tradycyjne, będące miniaturkami większych obiektów (podstawa czterokolumnowa lub jednokolumnowa); zawierające elementy rozbudowanych przyrządów, jak planetarium czy tellurium; mechaniczne (rodzaj zegara); kieszonkowe; „nawigacyjne” (w kwadratowych drewnianych pudełkach z płyta horyzontu) i „ręczne”, czyli luźno osadzone kule w drewnianych lub tekturowych pudełkach. Niekiedy trzy ostatnie grupy traktowane są razem jako globusy kieszonkowe. Zasadne zdaje się jednak podane wcześniej rozróżnienie, stosowane chociażby przez National Maritime Museum ${ }^{12}$. Nazwa „kieszonkowe” zastrzeżona jest wtedy dla wąskiej grupy obiektów o szczególnej konstrukcji, zgodnej ze standardem podanym przez ich twórcę - Josepha Moxona (1627-1691).

\section{Globusy kieszonkowe}

Autorską koncepcję globusa kieszonkowego opublikował Moxon w Proves of Several Sorts of Letters Cast by Joseph Moxon (Londyn 1669) ${ }^{13}$, później wykonał globus (1672) ${ }^{14}$. Peter van der Krogt uważa, że Moxon inspirował się, a nawet wzorował na technikach produkcji stosowanych przez oficynę Johannesa Blaeua

\footnotetext{
${ }^{11}$ E. Dekker, Globes at Greenwich, s. $128-132$.

${ }^{12}$ E. Dekker, Globes at Greenwich.

${ }^{13}$ D.J. Bryden, Early Printed Ephemera of London Instrument Makers. Trade Catalogues. Part. I: Joseph Moxon, 1673, „Bulletin of the Scientific Instrument Society", 64, 2000, s. 13-16.

${ }^{14}$ H. Wallis, A.H. Robinson, Cartographical Innovations. An International Handbook of Mapping Terms to 1900, Tring, Hertfordshire 1987, s. 32.
} 
(1596-1673) z Amsterdamu ${ }^{15}$. Obiekty wyróżniają się kompaktową formą - są to niewielkie globusy Ziemi, w kulistych etui, wewnątrz wyklejonych mapą nieba. Pod względem kartograficznym globusy te nie różnią się jednak od form tradycyjnych. Raz opracowane płyty miedziorytnicze pozwalały wydrukować segmenty map, używanych do oklejania kul osadzanych w różny sposób. Przykładowo Gerard Valk (1652-1726) oraz Leonard Valk (1675-1746) użyli mapy globusa Ziemi o średnicy $7,75 \mathrm{~cm}$ do wykonania globusa tradycyjnego, kieszonkowego oraz elementu tellurium (tab. 1). Jean Fortin (17401817) użył mapy globusa o średnicy $5,5 \mathrm{~cm}$ do wykonania zegara mechanicznego (tab. 1). Dlatego w tabeli zestawiono różne globusy miniaturowe, bowiem często odnajdywane są globusy kieszonkowe wytwórców znanych jedynie z tradycyjnych form. Przykładem jest globus Johna Senexa (1678-1740), licytowany na aukcji internetowej w 2009 r. ${ }^{16}$ Nie był sygnalizowany we wcześniejszych opracowaniach, chociażby u van der Krogta ${ }^{17}$.

Etui globusów kieszonkowych wykonywano z profilowanej tektury wzmacnianej szelakiem i oklejano ozdobną skórą. Odpowiednio wzmocnione, zabezpieczały globus przed uszkodzeniami mechanicznymi ${ }^{18}$. Składały się z dwóch półsfer, wyklejonych od wewnątrz papierową mapą nieba. Zdarzały się jednak egzemplarze odbiegające od standardu. Niekiedy etui było drewniane, oklejone mapa nieba od zewnątrz (np. globusy o śr. $5,80 \mathrm{~cm}$ i $6,80 \mathrm{~cm}$ Johanna Bernarda Bauera $)^{19}$. Niekiedy wewnątrz tradycyjnego etui nie

\footnotetext{
${ }^{15}$ P. van der Krogt, Globes. Made Portable for the Pocket, „Bulletin of the Scientific Instrument Society", 7, 1985, s. 8.

${ }^{16}$ Christie's. A 23/4-inch terrestrial pocket globe. Live Auction 2825: The Decorative Arts Sale 2009 (https://www.christies.com/lot/lot-a-2-inch-terrestrial-pocket-globe-i-senex-5219468/?from = searchresults\&intobjec$t \mid D=5219468$, dostęp: 16 grudnia 2020).

${ }^{17}$ P. van der Krogt, Old globes, s. 215.

${ }^{18} \mathrm{~S}$. Edell, Concave hemispheres of the starry orb., „Bulletin of the Scientific Instrument Society", 7, 1985, s. 6-8.

${ }^{19}$ E. Dekker, Globes at Greenwich, s. 273-274.
}

było mapy, a informacje astronomiczne (np. Newton Family) ${ }^{20}$. Ciekawym przykładem jest globus wykonany przez Johna Cary'ego (c. 1754-1835). Na wklejce zamiast mapy jest wykaz współrzędnych geograficznych miejscowości, które nie zmieściły się na globusie oraz mapa świata z czasów Cezara według Jean-Baptiste’a Bourguignona d'Anville'a (1697-1782) podpisana: „The WORLD as known in CAESAR'S Time/agreeable to D'Anvill" ${ }^{21}$.

\section{Obiekt badań}

Globus o numerze inwentarzowym MUJ $4118,118 / \mathrm{V}$ został zakupiony do zbiorów Muzeum Uniwersytetu Jagiellońskiego w roku 1991 z rąk prywatnych. Stan obiektu był taki jak obecnie. Mapa Ziemi mogła być poddana konserwacji. Po zakupie nie były prowadzone prace konserwacyjne w Muzeum.

Twórcą obiektu jest Johannes Deur (1667-1734) z Amsterdamu - kartograf, miedziorytnik i wytwórca globusów. Pochodził z rodziny o tradycjach w tej dziedzinie - jego ojciec Abraham Jansz. Deur (1640-1719) był miedziorytnikiem i kartografem, specjalizującym się w wielkoarkuszowych mapach ${ }^{22}$. Również brat Jacob (1673-1733) miał warsztat miedziorytniczy.

\section{Metody badawcze}

Globus jest obiektem muzealnym, dlatego prowadzone analizy nie mogły wykraczać poza zasady pracy z zabytkami. Studia obejmowały zagadnienia: budowę obiektu; stan zachowania; analizę mapy nieba oraz mapy Ziemi. Prace badawcze bazowały na szczegółowej dokumentacji fotograficznej i filmowej.

\footnotetext{
${ }^{20}$ Tamże, s. 424-426.

${ }^{21}$ P. van der Krogt, Old globes, s. 77-78; E. Dekker, Globes at Greenwich, s. 294-295; S. Edell, Concave hemispheres, s. 8.

${ }^{22}$ A.J. van der Aa, Biographisch Woordenboek der Nederlanden, t. 4, Haarlem 1858, s. 134; ECARTICO (http://www.vondel.humanities.uva.nl/ecartico/ persons/2423; dostęp: 4 grudnia 2020).
} 


\section{Rezultaty}

Badany obiekt składa się z dwóch elementów - globusa Ziemi oraz etui z mapą nieba (fot. 1). Kula o średnicy $6 \mathrm{~cm}$ wykonana jest $\mathrm{z}$ drewna liściastego (dąb lub buk), wytoczona w jednym kawałku. Na biegunach osadzone są dwa mosiężne trzpienie. Unieruchamiają one kulę w gniazdach opakowania.

Etui, o średnicy około $7 \mathrm{~cm}$, wykonane jest z tektury, oklejonej skórą szagrynową, barwioną na czarno. Mapa nieba w projekcji wewnętrznej umieszczona jest w postaci „wklejki”. Elementy zabezpieczające: zawias, haczyk zamykający i bolec wykonane są z mosiądzu. Krawędzie etui wzmocnione są metalowymi obręczami.

Mapy wykonane zostały w postaci dwunastu całościowych segmentów, w przypadku Ziemi dodatkowo dwóch kap biegunowych. Są ręcznie kolorowanymi miedziorytami, zabezpieczonymi werniksem (fot. 2). Użyto złota oraz sześciu barwników: żółtego, czerwonego, ciemnoczerwonego, błękitnego, ciemnozielonego, niebieskozielonego.

Mapa zachowana jest w dobrym stanie, werniks, choć lekko pożółkły, nie zaciemnia obrazu. Nieliczne pęknięcia papieru nie powodują jego odspojenia od podłoża. Jedynie przy krawędzi mapy nieba papier jest lekko przetarty. Na mapie Ziemi barwy są wypłowiałe, co może być efektem przeprowadzonych niegdyś zabiegów oczyszczania kuli (przed zakupem do Muzeum). $\mathrm{Na}$ krawędzi etui warstwy skóry i podłoża tekturowego są lekko przetarte, papier jest naruszony w kilku miejscach. Obecne sa nawarstwienia produktów korozji elementów mosiężnych. Kula jest w dobrym stanie, zastosowane drewno liściastych drzew jest twardsze od iglastych, bardziej odporne na uderzenia, wgniecenia i odkształcanie się. Kartusz z sygnowaniem: „AMSTERDAM / Excudit / Iohannes Deur” znajduje się na południowym Oceanie Indyjskim.

Mapa nieba przedstawiona jest $\mathrm{z}$ układem współrzędnych równikowych z naniesioną

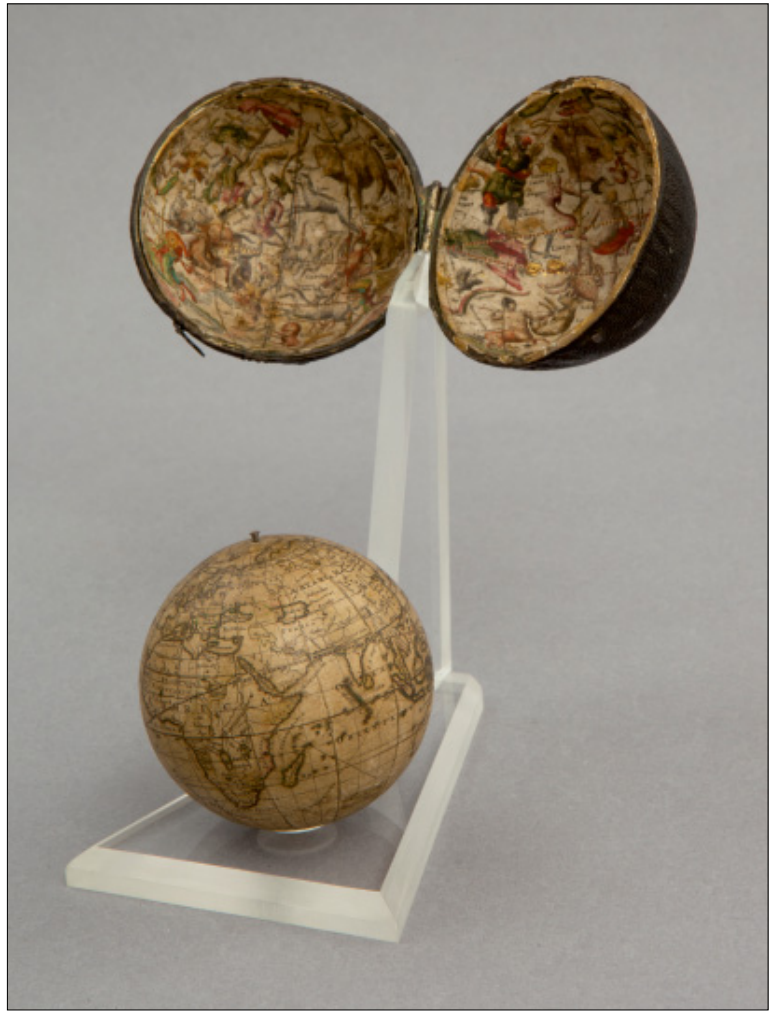

Fot. 1. Globus kieszonkowy, Johannes Deur, Amsterdam, 1699-1701, Muzeum UJ, fot. Grzegorz Zygier

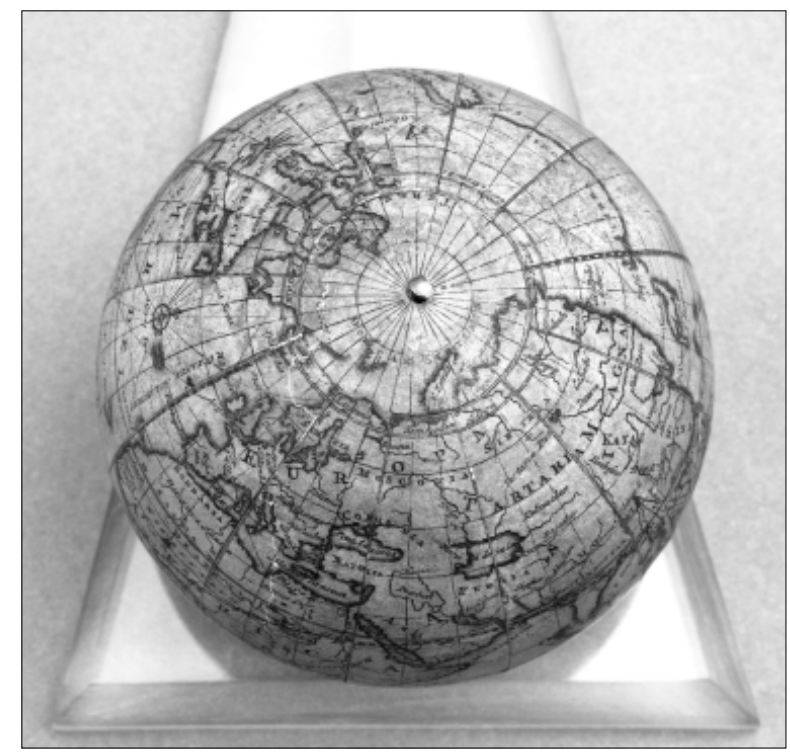

Fot. 2. Mapa Ziemi - biegun północny, Johannes Deur, Amsterdam, 1699-1707, Muzeum UJ, fot. Grzegorz Zygier 
siatką linii południków umieszczonych co 30 stopni oraz równikiem niebieskim. Dodatkowo narysowana jest ekliptyka, podobnie jak równik opisana co 10 stopni, działkę elementarną zaznaczono z dokładnością do jednego stopnia, naprzemiennie złotem i barwą czerwoną. Złotem zaznaczone są również główne gwiazdy, magnitudo (obserwowana wielkość gwiazdowa) w zakresie od $1^{\mathrm{m}}$ do $6^{\mathrm{m}}$, określona jest liczbą promieni. Kartusz Magnitudo stellarum umieszczony jest na południowej półkuli, na wschód od gwiazdozbioru Argo. Przy krawędzi mapy znajduje się sygnowanie: „AMSTERDAM / Excudit / I. Deur". Wizerunki gwiazdozbiorów są wzorowane na traktacie Jana Heweliusza (1611-1687) Prodromus astronomiae cum catalogo fixarum et firmamentum Sobiescianum $^{23}$. Szczególnie dobrze widać to na przykładzie konstelacji Sekstant, której detale są identyczne $\mathrm{z}$ ilustracjami z traktatu. Jednak podobieństwa dotyczą wszystkich gwiazdozbiorów.

Przedstawionych jest 78 konstelacji, odpowiadających siedemnastowiecznej wiedzy o niebie (tab. 2). Wśród nich sześć jest historycznych: Antoniusz, Argo, Cerber, Góra Menalus, Mucha Południowa i Dąb Karola. Okręt Argo Nicolaus Louis de Lacaille (1713-1762) rozdzielił w 1750 r. na Żagiel, Rufę i Kil. Największą i najstarszą grupą jest 48 gwiazdozbiorów (w tym Zodiak), przedstawionych przez Ptolemeusza (ok. 100 - ok. 168) w traktacie Almagest (połowa II w. n.e.). Krzyż Południa, zaznaczony przez Ptolemeusza jako część konstelacji Centaura, w samodzielny gwiazdozbiór wydzielony został przez Petrusa Placiusa (1613) lub Augusta Royera (1679). Drugą dużą grupą jest dwanaście konstelacji nieba południowego Pietera Dirksz. Keysera (ok. 1540-1596) i Fredricka de Houtmana (ok. 1571-1627). $\mathrm{Na}$ mapie przedstawił je Petrus Plancius

${ }^{23} \mathrm{~J}$. Heweliusz, Prodromus astronomiae cum catalogo fixarum et firmamentum Sobiescianum, Gdańsk 1690.
(1552-1622) w 1597 lub 1598 r., wprowadził on również gwiazdozbiór $\mathrm{Mu}$ chy Północnej (obecnie zlikwidowany), Żyrafy i Jednorożca. Trzecią dużą grupą są konstelacje Heweliuszowe - osiem aktualnych i dwie historyczne: Cerber (obecnie w konstelacji Herkulesa) i Góra Menalus (obecnie w południowej części Wolarza). Psy Gończe opisane są osobno jako Asterion i Chara. Umieszczony jest też Dąb Karola, autorstwa Edmonda Halleya (1656-1742). Ponadto konstelacje rzek: Jordan (Jordanis) i Tygrys (Tigris), pierwszy raz przedstawione przez Jakoba Bartscha (około1600-1633) w $1624 \mathrm{r}$. Jest też gwiazdozbiór Warkocz Bereniki duńskiego astronoma Tycho Brahego (1546-1601).

$\mathrm{Na}$ globusie Ziemi długość geograficzna oznaczona jest co jeden stopień, zaznaczona naprzemiennie okienkiem pustym i szarfowanym, opisana liczbowo co 10 stopni. Naniesione są: równik (Circulis Aequinectialis, opisany stopniami), zwrotniki (Tropicus Canceri, Tropicus Capricorni), koła podbiegunowe (Circulus Antarcticus, Circulus Arcticus) oraz ekliptyka (Aecliptica Zodiaci), oznaczone znakami zodiaku, opisane co 10 stopni, działka elementarna równa jeden. Południk zerowy przechodzi przez wyspę Ferro w archipelagu Wysp Kanaryjskich, działka elementarna co 1 stopień, nieopisana. Na globusie zaznaczone są elementy nawigacyjne: loksodromy, wybrane gwiazdy oraz uproszczona róża wiatrów (fot. 3). Poza wybrzeżami Europy, Azji, Afryki, obiema Amerykami znane też są fragmenty wybrzeży Australii i Oceanii. Brak jest Antarktydy, natomiast przy biegunie północnym widać zarys lądu (Terra Arctica). Linia brzegowa kontynentów i wysp została zaznaczona, a dodatkowo uplastyczniona cieniowaniem. Granice państw zaznaczone są barwnikami: czerwonym, żółtym i zielonym, miejscami zupełnie niewidocznymi. Na południku zerowym przy biegunie północnym zachowały się resztki złocenia. 
Ogólne zarysy Europy i Afryki narysowane są w miarę poprawnie (fot. 3 i 4). Azja sięga bardziej na wschód, przez co zmniejszyła się rozciągłość południkowa Pacyfiku. Kształt Ameryki Południowej jest prawidłowy, jedynie zatoki są bardziej wcięte, jest też ich więcej niż w rzeczywistości. Wybrzeża wschodnie i południowe Ameryki Północnej zostały prawidłowo odwzorowane, północne, północno-wschodnie i zachodnie przedstawiono z wieloma „białymi plamami”. Południowa część Ameryki Środkowej przedstawiona jest z wyprostowaną linią brzegową, poszerzona południkowo w obrębie Kostaryki i Panamy. Linia brzegowa kontynentów przedstawiona jest krzywą otwartą, dla terenów niezbadanych jest nienaniesiona. Mapa odpowiada stanowi wiedzy z końca XVII w.

Oceany opisane są w nieco innej konwencji niż obecnie. Na Atlantyku główną nazwą jest MAR DEL NORT, natomiast Oceanus Atlanticus naniesiony jest wzdłuż południka zerowego przy Europie. Dodatkowo zaznaczone są Mare Mexixanum, Sinus Mexicanus (Zatoka Meksykańska), Mar del Nort (nazwa występuje po raz drugi, tym razem nie użyto wersalików, określa Morze Sargassowe), M. Brasilicum, M. Paraguaium, Mare Magellanicum, Oceanus Meridionalis Aetiopicus (wokół Afryki od południa, zachodzi aż na Ocean Indyjski), Mare Mediterraneum, Pont Euxinus (Morze Czarne), Est Zee (Morze Bałtyckie). Ocean Indyjski opisany na środku jako OCEAN ORIENTALIS, a napis OCEANUS INDICUS przesunięty jest w kierunku Archipelagu Malajskiego. Ponadto zaznaczone są $M$. Langue Barie, M. Arabicum, Mare Rubrum, G[olf] de Bengalis. Na Pacyfiku główne podpisy to MAR DEL ZUR SIVE, MARE PACIFICUM umieszczone jako równorzędne, ponadto Mare Peruvianum, Mare de Chili oraz M. California.

Większe wyspy i archipelagi są zaznaczone oraz opisane, jak Haiti (Hispanola), Bahamy (Lucaye I.) czy Madagaskar.

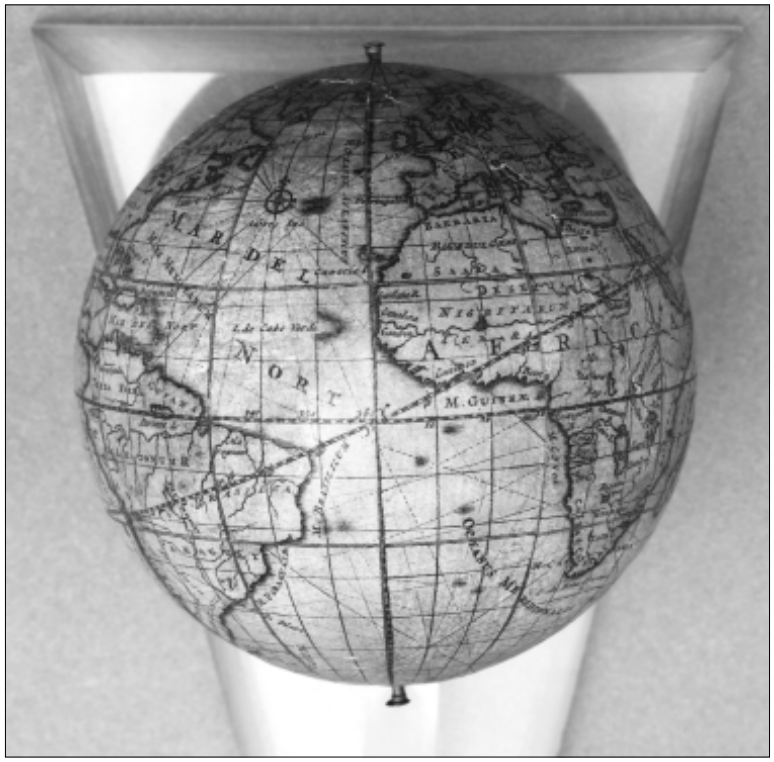

Fot. 3. Mapa Ziemi - Atlantyk, Johannes Deur, Amsterdam, 1699-1707, Muzeum UJ, fot. Grzegorz Zygier

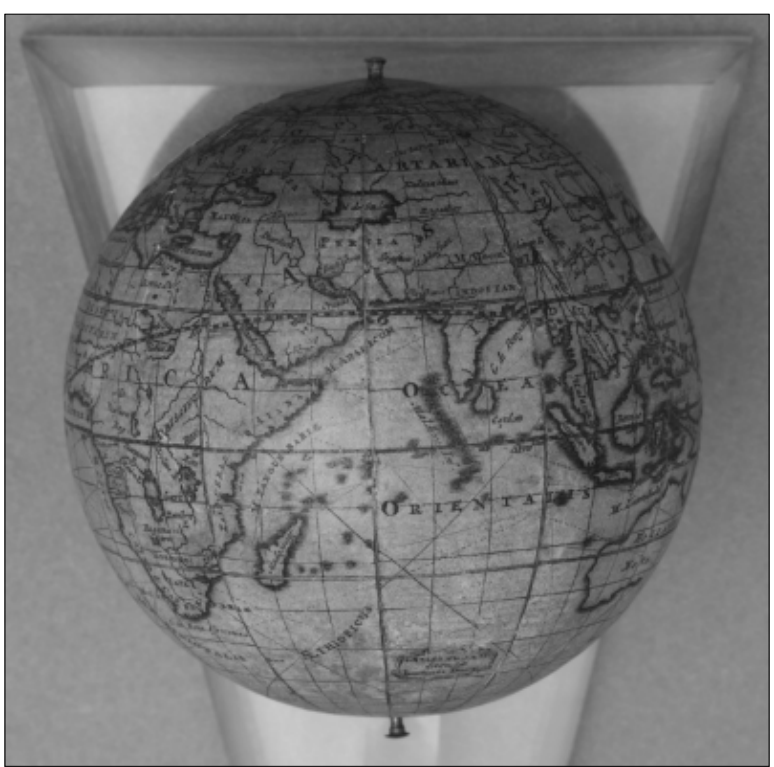

Fot. 4. Mapa Ziemi - Ocean Indyjski, Johannes Deur, Amsterdam, 1699-1707, Muzeum UJ, fot. Grzegorz Zygier

Mniejsze są zaznaczone, ale nie umieszczono ich nazw np. Seszele, Mauritius czy Reunion. Brak północnej części Grenlandii, linia brzegowa jest otwarta, wraz 


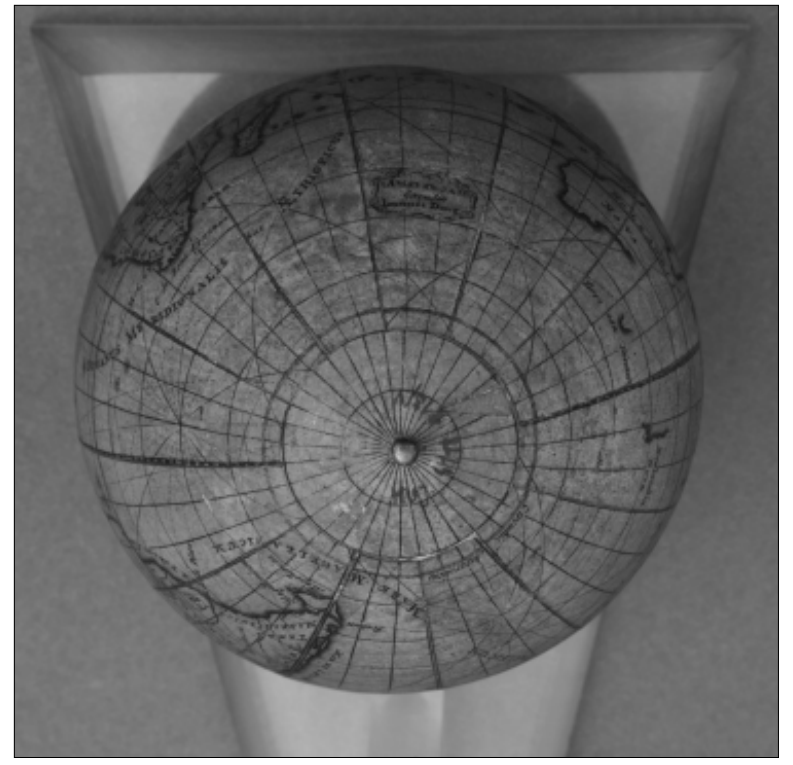

Fot. 5. Mapa Ziemi - biegun południowy, Johannes Deur, Amsterdam, 1699-1707, Muzeum UJ, fot. Grzegorz Zygier

z sąsiednimi rejonami oznaczona jako TERRA ARCT. Wokół bieguna północnego nie ma ziemi, wzdłuż osiemdziesiątego równoleżnika szerokości północnej umieszczona jest nazwa OCEANUS SEPTENTR. Dopiero północna linia brzegowa Azji jest narysowana. Brak Kamczatki i niektórych wysp (fot. 2).

Nazwy kontynentów zapisano pogrubionymi wersalikami, główne nazwy wersalikami, mniejsze delikatną czcionką, szczególnie liczne w Azji. Zaznaczone są główne jeziora oraz rzeki, niektóre opisane. Przykładowo w Europie z przedstawionych rzek: Peczora, Dwina, Wisła, Łaba, Ren, Loara, Tag, Rodan, Dunaj, Dniepr, Don, Wołga z Kamą, Ural, opisane są tylko Dwina i Wołga (fot. 2).

Napis EUROPA rozciagnnięty jest aż do ujścia rzeki $\mathrm{Ob}$ (fot. 5), wersalikami wyróżnione są tylko dwa państwa: MOSCOVIA i SUECIA, większość krajów europejskich podpisana została: Germania, Gallia, Hispania, Portugallia, Hollandia (częściowo niewyraźny napis), Dania, Norvegia, Hungaria, Polonia, Grecia, Italia, Anglia, Scotia,
Hibernia (Irlandia), Islandia, Commania (terytoria Kumanów), S[er]gia, Laponia, Walachia (Nizina Wołoska).

Napis ASIA rozciągnięty jest na skos kontynentu, wyróżnione wersalikami są: TARTARIA MAGNA, KATAI SINA, INDOSTAN, INDIA, PERSIA, ARABIA, NATOLIA (Turcja), I. IAPONIA, KALMAC$K E N$, SINE PARIS (??), BISMAN (??), SUCHUEN, SIAM, MALUCCA. Półwysep Kolski kończy się za 60 południkiem (liczonym od Ferro), czyli jest o blisko 10 stopni na wschód w stosunku do właściwego położenia (fot. 6). Nowa Ziemia (N. Zemla) wrysowana jest jako jedna wyspa, bez cieśniny Matoczkin Szar. Jest natomiast Hanan, I. Formosa (Tajwan) czy I. Japonia. Zaznaczone M. DE SALA (Morze Słonawe, czyli Kaspijskie), nie ma morza Aralskiego (fot. 2, 4).

Informacja $A F R I C A$ umieszczona jest równoleżnikowo na południu Sahary. Wyróżnione nazwy: ZANGUEBARIANA, ABBISSINORUM, COMANIA, SAARA DESERIA [Pustynia Sahara], BILEDULGERID (z arabskiego biléd kraj, el-gerid palma), NIGRITARUM TERRA, SIBIRIA, $B A R B A R I A$. Wielkie jeziora przesunięte są bardziej dośrodkowo, zmieniono ich proporcje i kształty, dwa wielkie jeziora zostały wyrysowane jako źródła Nilu. Na północy jest wielka rzeka płynąca równoleżnikowo przez większość kontynentu (fot. 3), według innych map jest to Niger.

Nazwę AMERICA poprowadzono południkowo przez oba kontynenty. Brak informacji o północnej części wybrzeża zachodniego Ameryki Północnej, północnych wyspach oraz terenach wokół Zatoki Hudsona. Główne nazwy to NOVA FRANCIA, FLORIDA, HISPANIA NOVA, California, osobno przedstawiona jest Alaska jako TERRA SOMIS; Ameryka Środkowa: NOVA MEXICO, Yucatan; Ameryka Południowa: TERRA FIRMA, AMAZONORUM, GUIANA, PERU, PARAGUAY, CHILE, TERRA MAGELLANICA, BRASILIA (fot. 3, 7). 
W przypadku Australii zaznaczone są tylko wybrzeża zachodnie, północne i południowo-zachodnie. Fragmentarycznie wrysowane zostały również Tasmania (Terra van Diemen), Wyspa Południowa Nowej Zelandii i znaczna część Nowej Gwinei (rozdzielonej na dwie wyspy). Dodatkowo umieszczony jest fragment lądu opisany jako Quiru Regio. Australia, opisana jako Hollandia Nova, oddzielona przez M. Lantchildel od wyspy Timur (fot. 6).

Część informacji jest kompilacją legend, fragmentarycznych danych i starych dokumentów. Kalifornia została przedstawiona jako rozległa wyspa. F[retum] Aniani, czyli Cieśnina Anian, to element hipotetycznego Przejścia Północno-Zachodniego, oddzielała od Ameryki Terra Somis czyli mityczny Gamaland (fot. 6). W Ameryce Południowej znajduje się jezioro Parime (Parime L.), nad którym miało się znajdować mityczne El Dorado (fot. 3). W Afryce umieszczono potężną rzekę Niger, mającą źródła w ,jeziorze Niger”, a ujście w Atlantyku. Początkowo płynie ona południkowo w górę, następnie skręca w okolicach jeziora Czad (brak) na zachód i w układzie równoleżnikowym, nie zmieniając kierunku, przepływa przez wielkie niepodpisane jezioro, kierując się do zachodniego wybrzeża. Nil przedstawiono ze źródłami w wielkich jeziorach: Zaslan oraz Zair (wypływa Nil Biały oraz Zair). Wśród legendarnych nazw znajdziemy: Tartaria Magna (Azja Północna i Środkowa), Commania, wywodzona do Kumanów, czyli Połowców (na Nizinie Czarnomorskiej). W Afryce BARBARIA, jako kraj Maghrebu (dzisiejsze Maroko, Algieria i Tunezja). W Europie Hibernia, określająca Irlandię (fot. 2).

W Ameryce, Australii i Oceanii jest wiele nazw nawiązujących do toponimów europejskich - jak Nowa Zelandia, Nowa Funlandia, Hollandia Nova (Australia), Hispania Nova (Meksyk). Większość obecnie nosi inne nazwy, szczególnie w Ameryce Północnej, chociażby Nova

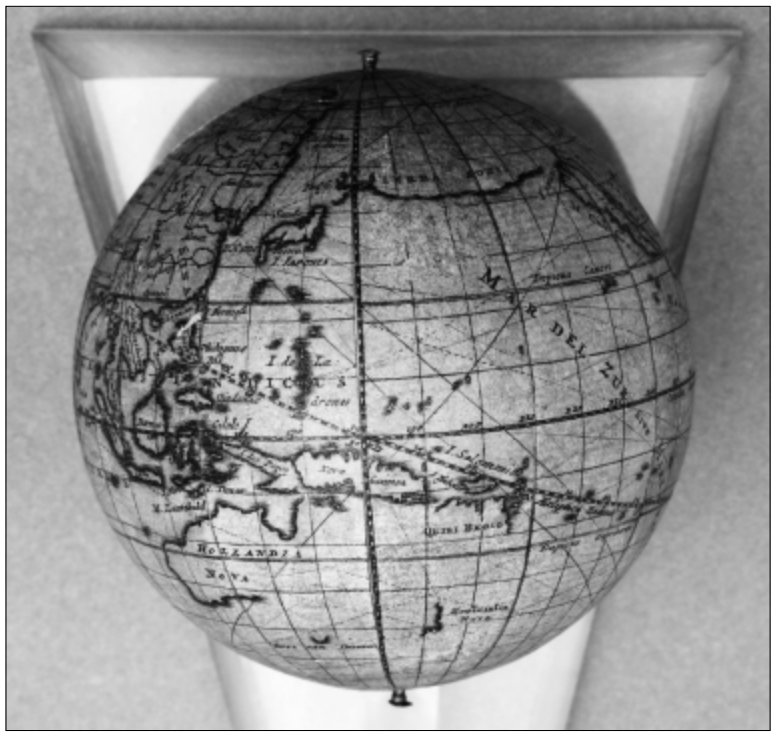

Fot. 6. Mapa Ziemi - Pacyfik, Johannes Deur, Amsterdam, 1699-1707, Muzeum UJ, fot. Grzegorz Zygier

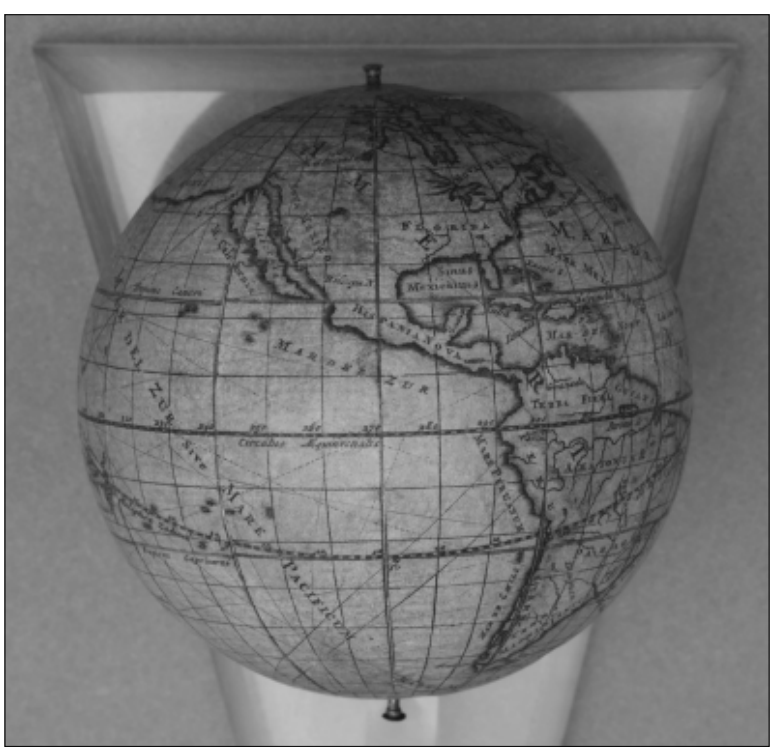

Fot. 7. Mapa Ziemi - Ameryka, Johannes Deur, Amsterdam, 1699-1707, Muzeum UJ, fot. Grzegorz Zygier

Francia (Kanada Wschodnia, Akadia), Nova Britagnia (Kanada Północna). Domena Hiszpańska - posiadłości w Ameryce Południowej i części Panamy podpisane jako Terra Firma (fot. 7). Odróżniano tak posiadłości hiszpańskie na kontynencie od 
tych położonych na wyspach (Spanish West Indies, Spanish Antilles).

\section{Dyskusja}

Podstawowym zagadnieniem w analizie zabytków jest autorstwo i datowanie. Kartusze na globusie Ziemi i mapie nieba mają uproszczoną sygnaturę, podającą tylko wytwórcę i miejscowość (fot. 5). Johannes Deur mógł wcześniej praktykować u ojca. Swój warsztat prowadził w Amsterdamie w latach 1699-173424, choć według van Krogta przypadało to na lata $1700-1725^{25}$, niekiedy nawet uznawano okres $1702-$ $1714^{26} .25$ czerwca 1722 r. Deur uzyskał od parlamentu Staten van Holland en West-Friesland przywilej produkcji mechanicznych globusów ${ }^{27}$. Według Enrica Morpurga rok później został zarejestrowany jako producent globusów ${ }^{28}$. Jakość wykonania i wykończenia globusów Deura, zarówno jako obiektów kartograficznych, jak i dzieł sztuki, wysoko plasuje je wśród innych globusów miniaturowych. Obok Johannea Janssoniusa (1588-1664) czy Valków Deur był jednym z trzech pionierskich autorów globusów kieszonkowych w Amsterdamie ${ }^{29}$. Treść mapy omawianego globusa nie przedstawia nowych odkryć, znanych już w na początku XVIII w. Zachowany w Muzeum UJ egzemplarz pochodzi najprawdopodobniej z pierwszej edycji, wykonanej przez Deura. Można więc się spodziewać, że umieścił najbardziej aktualne znane sobie informacje.

Przybliżone datowanie ułatwia obecność dwóch map wykonanych w jednym okresie. W odróżnieniu od par globusów, rozbieżność dat nie może być duża. Mapa

\footnotetext{
${ }^{24}$ Ecartico, Linking cultural industries in the early modern Low Countries, ca. 1475 - ca. 1725. Abraham Jansz. Deur (http://www.vondel.humanities. uva.nl/ecartico/persons/2423, dostęp: 9 stycznia 2021).

${ }^{25}$ P. van der Krogt, Old globes, s. 106-107.

${ }^{26}$ R.S. Webster, M.K. Webster, Signature Database, Adler Planetarium (http:// www.adlerplanetarium.org, dostęp: 6 stycznia 2021).

${ }^{27}$ P. van der Krogt, Globi Neerlandici. The production of globes in the Low Countries, Utrecht 1993, s. 359; E. Dekker, Globes at Greenwich, s. 65.

${ }^{28}$ E. Morpurgo, Nederlandse klokken- en horlogemakers vanaf 1300 , Amsterdam 1970, s. 33

${ }^{29}$ P. van der Krogt, Old globes, s. 106-107.
}

nieba wykonana została w oparciu o wykaz Heweliusza (po 1690) a przed śmiercią Deura (1734). Mapa Ziemi jest bardziej pomocna. Treść globusa Ziemi jest analogiczna do prac niderlandzkich z przełomu XVII i XVIII w. Jednak chociażby na mapach Pietera van der Aa z 1707 r. Papua oddzielona jest już od Nowej Gwinei ${ }^{30}$, a kształt Wielkich Jezior Północnoamerykańskich prawie kompletny ${ }^{31}$. Uzupełnione są więc o informacje $\mathrm{z}$ wyprawy Louisa Hennepina (1626-1704) z 1698 r. $^{32}$ Warto również uwzględnić, że na pracy Heinricha Scherera (1628-1704) America Borealis z 1699 r. jest już wyraźny kształt wspomnianych jezior ${ }^{33}$. Charakterystyczny „palczasty” kształt Wielkich Jezior Północnoamerykańskich, który pojawia się na globusie Deura, odnaleźć można w pracach Nicolasa Sansona (1600-1667): Mappemonde Geo-Hydrographique..., wydanej w Atlas Nouveau (Paryż 1692-1693) ${ }^{34}$ czy Amerique Septentrionalis divise en ses principale parties (Paryż 1692).

Na globusie Deura nie ma zaznaczonej Kamczatki i Półwyspu Czukockiego, powinna więc być wykonana przed $1701 \mathrm{r}$. Jednak na mapach wykonanych na początku XVIII w. w Amsterdamie te obszary również nie są naniesione. Biorąc pod uwagę wspomniane wcześniej mapy van der Aa, globus musiał powstać przed rokiem 1707. Najlogiczniejszy wydaje się przedział 1699-1701, choć nie ma dla tego wyraźnych przesłanek. Dlatego bezpieczniej jest przyjąć czas jego powstania na lata 1699-1707.

Obecnie znane są zaledwie trzy egzemplarze globusów kieszonkowych autorstwa

\footnotetext{
${ }^{30}$ P. van der Aa, Scheeps-Togt door Ferdinand Magellaan uit Kastilien gedaan na R. de laPlata en van daar door zyn Ontdekte Straat tot aan de Moluccas, Amsterdam 1707

${ }^{31}$ P. van der Aa, T Noorder Deel Van Amerika door C. Kolumbus, Amstedam 1707.

${ }^{32}$ Carte d'un tres grand pays..., L. Hennepin, 1698, za: Wikipedia (dostęp: 5 stycznia 2021)

${ }^{33}$ H. Scherer, Atlas Novus, Monachium 1702-1710.

${ }^{34}$ H. Jaillot, N. Sanson, Atlas Nouveau, 1692-1993, (https://pl.wikipedia. org/wiki/Plik:1691 Sanson Map of the World on Hemisphere Projection - Geographicus - World2-sanson-1691.jpg, dotęp: 5 stycznia 2021).
} 
Deura. W wykazie Index of Globes and Globe Makers z XIX w. znajduje się również informacja o jeszcze jednym egzemplarzu tego wytwórcy ${ }^{35}$. Nie wiadomo jednak nic pewnego o jego losach. Poza krakowskim (pierwsze wydanie), jeden jest przechowywany w Muzeum Boerhaave w Lejdzie (drugie wydanie). Opisany był przez van der Krogta, który datował go na wczesny XVIII w. ${ }^{36}$ Trzeci globus sprzedano na aukcji Christie's 23 kwietnia 2013 r. ${ }^{37}$ Sygnatura wskazuje, że chodzi tu o pierwszą edycję mapy, tym samym został wykonany w oparciu o tę samą płytę miedziorytniczą co krakowski. Dom aukcyjny datował globus na „około 1720 r." Zamieszanie mogła wprowadzić informacja o uzyskaniu przez Deura przywileju z 1721 r., jednak dotyczyła produkcji globusów mechanicznych, a nie kieszonkowych.

Egzemplarz oferowany na aukcji ma lepiej zachowane barwy mapy Ziemi niż krakowski. Zdobione złotem są tam południk zerowy, zwrotniki i koła podbiegunowe, jak również obramowanie kartusza. Ekliptyka i równik wykreślone są z podziałem zaznaczonym naprzemiennie złotem i kolorem czerwonym (na krakowskim zachowała się tylko czerwona barwa). Kolorem ciemnozielonym oznakowane są kontury wysp, nawet tych najmniejszych, podobnie jak i jezior. Granice krajów i dominiów wyeksponowano kolorami czerwonym, koralowym, zielonym, turkusowym i żółtym, przykładowo granice Polonii zaznaczono barwą turkusową. W przypadku mapy nieba stan zachowania obu eksponatów jest podobny.

Mapa nieba umieszczana w kulistych etui globusów kieszonkowych znajduje się na dwóch półczaszach. Istotnym

\footnotetext{
${ }^{35}$ F. Muller, Index of Globes and Globe Makers, w: Catalogue de Geographie, Cartographie, Voyages, No. 93. Amsterdam 1891; E.L. Stevenson, Terrestial nad celestial globes..., t. 2, Londyn 1921, s. 259; P. van der Krogt, Globi Neerlandici, s. 572.

${ }^{36} \mathrm{P}$. van der Krogt, Old globes, s. 106.

${ }^{37}$ Christie's. A Dutch $2 \frac{1}{2} 2$-inch pocket globe, Johannes Deur, circa 1720. Live Auction 8668: Travel, Science and Natural History 2013 (https://www. christies.com/en/lot/lot-5672833, dostęp: 20 grudnia 2020).
}

elementem jest poprowadzenie linii cięcia mapy - najczęściej na półkulę północną i południową. Jest to zgodne z przedstawieniami z atlasów (np. Heweliusza). Zasadę tę przyjął Moxon. Deur zerwał z tradycją, dzieląc mapę wzdłuż południków. Taki podział mają jeszcze globusy firmy Charls Smith \& Son (Amsterdam, 1834) oraz T. Harris \& Son (Londyn, pocz. XIX w.). Miało to uzasadnienie - poprawiało czytelność konstelacji w rejonie równika (poza samą linią cięcia). Natomiast okolice biegunów stawały się prawie nieczytelne. Jest to ciekawe rozwiązanie, mapa pokryta jest równomiernie wizerunkami. W globusach, w których w mapa nieba dzielona jest wzdłuż równika (np. Moxon, Senex, Newton), południowa półkula miała wiele pustych przestrzeni, optycznie stanowiąc opozycję do północnej hemisfery.

Mapy globusów kieszonkowych miały różną dokładność. Prace Deura cechuje duża liczba szczegółów i staranność wykonania. Niewielkie rozmiary powodują jednak, że globusy te nie mogły być dokumentem nawigacyjnym. Koszt ich zakupu był wysoki, choć mniejszy nieco niż pary globusów. Globus Moxtona z lat siedemdziesiatych XVII w. kosztował około 15 szylingów, czyli niecały funt (do $1971 \mathrm{r}$. na funt składało się 20 szylingów). Była to niemała kwota nawet sto lat później. Niewykwalifikowany robotnik zarabiał 12 szylingów na tydzień (1793), wynajęcie dorożki w Londynie na 45 minut kosztowało 1 szyling, a trzydziestosześciogalonowa beczka piwa 10 szylingów $(1793)^{38}$. Zaletą globusików była poręczność, lekkość i możliwość schowania w kieszeni. Bogate materiały wykończeniowe dodawały blasku i splendoru. Globusy kieszonkowe były raczej bibelotami gentelmanów, a nie tanimi przyrządami używanymi przez podróżnych ${ }^{39}$.

\footnotetext{
${ }^{38}$ P. Dobrowolski, Watch your pocket - krótka historia zamożności, czyli kradzieże zegarków w Londynie w XVIII w., „Kwartalnik Historii Kultury Materialnej", 63 (3), 2015, s. 451-470, s. 466.

${ }^{39}$ Np. E. Dekker, Pocket globe.
} 
Idea i konstrukcja obiektu była udana, skoro globusy kieszonkowe wydawano nadal w XIX w., choć ekskluzywne i drogie obiekty najczęściej zastępowane były tańszymi. Zamiast etui obitych skórą szagrynową stosowano zazwyczaj drewniane, a nawet tekturowe pudełka. Jednak nawet dziś oferowane są obiekty kolekcjonerskie - chociażby kieszonkowe globusy księżycowe w skórzanych etui wydawane przez NASA ${ }^{40}$. Małe globusy (miniaturowe) produkowano nadal po 1800 r. przede wszystkim jako pomoce dydaktyczne dla uczniów $^{41}$. Niekiedy towarzyszyły im dodatkowe elementy, chociażby tablice prezentujące mieszkańców poszczególnych regionów kuli ziemskiej - jak obiekty wykonane przez Bauer Family (1800-1805). W Holbrook Apparatus Manufacturing Co w USA produkowało adresowane specjalnie dla uczniów rozkładane drewniane globusy z planiglobami umieszczonymi na przekroju kuli.

\section{Podsumowanie}

Przechowywany w Muzeum Uniwersytetu Jagiellońskiego globus jest dziełem Johannesa Deura, datowanym na okres 1699-1707. Obecnie znane są zaledwie trzy globusy kieszonkowe Deura zachowane do naszych czasów. Omawiany obiekt, wraz z licytowanym na aukcji w 2013 r., pochodzą z pierwszej edycji, natomiast globus zachowany w Lejdzie $\mathrm{z}$ drugiej.
Jest to typowy przykład globusa kieszonkowego. Zastosowane materiały, w tym złoto oraz rysunek map wyróżniają go wśród innych obiektów tego typu. Omawiany przedmiot ma wszelkie cechy ekskluzywnego przyrządu, produkowanego w niedużych ilościach. Pierwsze globusy kieszonkowe były kosztownymi bibelo$\operatorname{tami}^{42}$. Wprowadzenie techniki druku litograficznego zmniejszyło istotnie koszty produkcji. Dlatego globusy, w tym również te miniaturowe, spopularyzowały się, stając się łatwo dostępnymi pomocami dydaktycznymi.

Prezentowana mapa Ziemi przedstawia obraz zgodny z wiedzą o świecie z przełomu XVII i XVIII w. Brak jest ważnych odkryć z początku XVIII w., głównie półwyspu Kamczatki i regionów przyległych. Również zarys Wielkich Jezior Ameryki Północnej nie zgadza się z wizerunkami z początku XVIII w.

W stosunku do rozmiarów mapa jest wyrysowana szczegółowo, z dużą ilością informacji. Jest czytelna i stanowi doskonały obraz wiedzy astronomicznej i kartograficznej z tego okresu.

Ikonografie gwiazdozbiorów są wzorowane na katalogu Heweliusza z 1690 r. Mapa wykonana jest w projekcji wewnętrznej, typowej dla globusów kieszonkowych. Jednak południkowa linia cięcia odbiega od stosowanej zazwyczaj równoleżnikowej.

\footnotetext{
${ }^{40}$ Full Moon (http://thelittleglobeco.com/new-products/full-moon, dostęp 1 grudnia 2020).

${ }^{41}$ E. Dekker, Pocket globe.
}

$\overline{{ }^{42} \text { S. Edell, Concave hemispheres, s. } 6 .}$ 
Tabela. 1. Wykaz wydań zabytkowych miniaturowych globusów, wykonanych do połowy XIX w.

\begin{tabular}{|c|c|c|c|c|c|c|}
\hline Wytwórca & Miejscowość & Średnica [cm] & Data powstania & $\begin{array}{l}\text { Rodzaj } \\
\text { globusa }\end{array}$ & Uwagi & Źródło \\
\hline anonim & Amsterdam? & 3,80 & XVII/XVIII & $\mathrm{t}$ & dla lalek & $\mathrm{K}$ \\
\hline anonim & $\mathrm{nn}$ & 7,00 & ok. 1775 & k & & D \\
\hline anonim & $\mathrm{nn}$ & 8,50 & ok. 1800 & k & $\mathrm{m}$, srebro & $\mathrm{D}$ \\
\hline \multirow{6}{*}{ Dudley Adams } & \multirow{6}{*}{ Londyn } & 7,00 & ok. 1770 & k & & $\mathrm{D}$ \\
\hline & & 7,60 & 1795 & $\mathrm{k}$ & $f$ & $\mathrm{D}$ \\
\hline & & 7,60 & 1808 & k & & $\mathrm{D}$ \\
\hline & & 7,60 & po 1833 & $\mathrm{k}$ & & $\mathrm{D}$ \\
\hline & & 7,00 & 1773 & $\mathrm{i}$ & & $\mathrm{K}$ \\
\hline & & 7,60 & & $\mathrm{k}, \mathrm{pr}$ & $\begin{array}{l}\text { ze sferą } \\
\text { armilarną }\end{array}$ & $\mathrm{D}$ \\
\hline Thomas Marriott Bardin & Londyn & 3,75 & ok. 1800 & $\mathrm{i}$ & & $\mathrm{D}$ \\
\hline Robert Brettell Bate & Londyn & 7,60 & 1818 & k & & $\mathrm{I} .10$ \\
\hline \multirow{5}{*}{$\begin{array}{l}\text { Bauer Family: Johann } \\
\text { Bernard Bauer; Carl } \\
\text { Johann Sigmund Bauer; } \\
\text { Peter Bauer }\end{array}$} & \multirow{5}{*}{ Norymberga } & 5,80 & ok. 1810 & $k$, ed & d & $\mathrm{D}$ \\
\hline & & 4,30 & $1800-1825$ & $s$ & $\begin{array}{l}\text { z kartami } \\
\text { mieszkańców } \\
\text { regionów }\end{array}$ & $\mathrm{D}$ \\
\hline & & 7,00 & 1791 & $\mathrm{t}$ & $d$ & $\mathrm{~K}$ \\
\hline & & 10,00 & ok. 1800 & $\mathrm{t}$ & d & $\mathrm{K}$ \\
\hline & & 6,80 & $188-1825$ & $\mathrm{k}$, ed & d & $\mathrm{D}$ \\
\hline Willem Jansz. Blaeu & Amsterdam & 10,00 & 1616 & $\mathrm{t}, \mathrm{pr}$ & & $\mathrm{K}$ \\
\hline \multirow[t]{2}{*}{$\begin{array}{l}\text { Cary Family; John Cary } \\
\text { i synowie George oraz } \\
\text { John }\end{array}$} & \multirow[t]{2}{*}{ Londyn } & 8,00 & 1791 & k & $\begin{array}{l}\text { mapa świata } \\
\text { Cezara i wykaz } \\
\text { miejscowości } \\
\text { nieujętych na } \\
\text { globusie ze } \\
\text { współrzędnymi }\end{array}$ & $\mathrm{D}, \mathrm{K}$ \\
\hline & & 8,00 & ok. 1825 & $\mathrm{t}, \mathrm{pr}$ & & $\mathrm{K}$ \\
\hline \multirow{2}{*}{ Vincenzo Coronelli } & \multirow{2}{*}{ Wenecja } & 5,00 & 1693 & $\mathrm{t}, \mathrm{pr}$ & & $\mathrm{K}$ \\
\hline & & 8,50 & 1697 & $\mathrm{t}, \mathrm{pr}$ & & $\mathrm{K}$ \\
\hline James Cox & Londyn & 7,60 & 1839 & $\mathrm{k}$ & & $\mathrm{I} .13$ \\
\hline Richard Cushee & Londyn & 7,00 & 1731 & $\mathrm{k}$ & & $\mathrm{D}, \mathrm{K}$ \\
\hline \multirow{2}{*}{$\begin{array}{l}\text { Charles-Francois } \\
\text { Delamarche }\end{array}$} & \multirow{2}{*}{ Paryż } & 5,50 & ok. 1790 & $\mathrm{i}$ & & $\mathrm{D}, \mathrm{K}$ \\
\hline & & 8,00 & po 1851 & $\mathrm{i}$ & & $\mathrm{D}$ \\
\hline \multirow{2}{*}{ Johannes Deur } & \multirow{2}{*}{ Amsterdam } & 6,00 & $1699-1700$ & k & L (2 sztuki) & $\mathrm{T}, \mathrm{I}$ \\
\hline & & 6,00 & pocz. XVIII & $\mathrm{k}$ & I & $\mathrm{K}$ \\
\hline \multirow{2}{*}{$\begin{array}{l}\text { Johann Gabriel } \\
\text { Doppelmayr }\end{array}$} & \multirow{2}{*}{ Amsterdam } & 10,00 & 1736 & $\mathrm{t}$ & $n, d$ & $\mathrm{~T}$ \\
\hline & & 10,00 & 1736 & $\mathrm{t}, \mathrm{pr}$ & $d$ & $\mathrm{~K}$ \\
\hline
\end{tabular}




\begin{tabular}{|c|c|c|c|c|c|c|}
\hline Wytwórca & Miejscowość & Średnica [cm] & Data powstania & $\begin{array}{l}\text { Rodzaj } \\
\text { globusa }\end{array}$ & Uwagi & Źródło \\
\hline Peter Driessens & Bruksela & 5,40 & 1828 & i & & $\mathrm{K}$ \\
\hline $\begin{array}{l}\text { Endersch Johann } \\
\text { Friedrich }\end{array}$ & Elbląg & 7,30 & 1740 & $t$ & $\mathrm{n}$ & $\mathrm{T}$ \\
\hline \multirow{2}{*}{ James Ferguson } & \multirow{2}{*}{ London } & 7,60 & 1756 & $k$ & & $\mathrm{D}$ \\
\hline & & 7,60 & 1757 & s & $\mathrm{n}$ & $\mathrm{D}$ \\
\hline \multirow{4}{*}{ Jean Fortin } & \multirow{4}{*}{ Paryż } & 5,50 & ok. 1770 & $z$ & & $\mathrm{D}$ \\
\hline & & 5,50 & 1773 & i & & $\mathrm{K}$ \\
\hline & & 6,70 & 1770 & $\mathrm{t}, \mathrm{pr}$ & & $\mathrm{K}$ \\
\hline & & 6,70 & 1770 & $k$, ebn & & $\mathrm{D}$ \\
\hline W. Goodison & Londyn & 7,60 & poł. XVIII & $\mathrm{t}, \mathrm{pr}$ & $\begin{array}{l}\text { w gniazdach, } \\
\text { statywy na } \\
\text { nóżkach }\end{array}$ & I.1 \\
\hline Güssefeld Franz Ludwik & Weimar & 9,00 & ok. 1805 & $t$ & $\mathrm{n}$ & $\mathrm{T}$ \\
\hline Jacques i Nicolas Hardy & Paryż & 7,00 & 1738 & $\mathrm{t}, \mathrm{pr}$ & & $\mathrm{D}$ \\
\hline \multirow{2}{*}{ Nataniel Hill } & \multirow{2}{*}{ Londyn } & 7,00 & 1754 & i & & $\mathrm{K}$ \\
\hline & & 7,00 & 1754 & $k$ & & $\mathrm{~K}, \mathrm{I} .2, \mathrm{DG}$ \\
\hline T. Harris \& Son & Londyn & 7,60 & pocz. XIX & $\mathrm{k}$ & I & $\mathrm{I} .14$ \\
\hline $\begin{array}{l}\text { Holbrook Apparatus } \\
\text { Manufacturing Co }\end{array}$ & Wethersfield & 7,60 & $1830-1859$ & $k$ & $\begin{array}{l}\text { kula rozkłada- } \\
\text { na, planigloby }\end{array}$ & 1.7 \\
\hline Johann Baptist Homann & Norymberga & 5,08 & 1715 & $\mathrm{k}$ & $\begin{array}{l}\text { rozkładany } \\
\text { globus ziemi, } \\
\text { sfera armilarna } \\
\text { wewnątrz }\end{array}$ & $S$ \\
\hline Jodocus Hondius & Amsterdam & 8,00 & ok. 1600 & $t$ & & $\mathrm{~K} 1$ \\
\hline \multirow{2}{*}{ Johannes Janssonius } & \multirow{2}{*}{ Amsterdam } & 9,50 & 1620 & $z$ & & $\mathrm{D}$ \\
\hline & & 9,50 & 1650 & $z$ & & $\mathrm{D}$ \\
\hline \multirow{2}{*}{ William i Samuel Jones } & \multirow{2}{*}{ Londyn } & 3,50 & ok. 1800 & i & & $\mathrm{D}$ \\
\hline & & 3,50 & 1794 & i & & $\mathrm{K}$ \\
\hline Pieter van der Keere & Amsterdam & 9,50 & 1613 & $\mathrm{t}, \mathrm{pr}$ & & $\mathrm{K} 1$ \\
\hline Abraham van Keulen & Amsterdam & $2 "$ & 1697 & $k$ & & $\mathrm{~K} 1$ \\
\hline \multirow{6}{*}{$\begin{array}{l}\text { Johann Georg Klinger } \\
\text { Klinger Kunsthandlung }\end{array}$} & \multirow{6}{*}{ Norymberga } & 4,30 & 1800 & pr, ebn & & $\mathrm{D}$ \\
\hline & & 4,30 & ok. 1850 & s & $\mathrm{h}$ & $\mathrm{D}$ \\
\hline & & 5,70 & ok. 1800 & k, ebn & & $\mathrm{D}$ \\
\hline & & 7,50 & ok. 1850 & s & $\mathrm{h}$ & $\mathrm{K}$ \\
\hline & & 10,00 & ok. 1850 & s & $\mathrm{h}$ & $\mathrm{K}$ \\
\hline & & 10,00 & ok. 1850 & $t$ & $d$ & $\mathrm{~K}$ \\
\hline Industries Comtoir Lands & Weimar & 10,00 & 1798 & s & $\mathrm{h}$ & $D$ \\
\hline
\end{tabular}




\begin{tabular}{|c|c|c|c|c|c|c|}
\hline Wytwórca & Miejscowość & Średnica [cm] & Data powstania & $\begin{array}{l}\text { Rodzaj } \\
\text { globusa }\end{array}$ & Uwagi & Źródło \\
\hline \multirow{5}{*}{ Nicolas Lane } & \multirow{5}{*}{ Londyn } & 7,00 & 1776 / po 1776 & $\mathrm{k}$ & & $\mathrm{D}, \mathrm{K}$ \\
\hline & & 7,00 & 1807 & $\mathrm{k}$ & & V \\
\hline & & 7,00 & 1818 & $\mathrm{k}$ & & $\mathrm{K}$ \\
\hline & & 7,60 & po 1833 & $\mathrm{k}$ & & $\mathrm{D}, \mathrm{K}$ \\
\hline & & 5,08 & 1809 & $\mathrm{t}$ & $\begin{array}{l}\text { na podstawie } \\
\text { mosiężnej }\end{array}$ & 1.3 \\
\hline Malby \&Co & Londyn & 4,00 & 1842 & $\mathrm{i}$ & & $D$ \\
\hline John Miller & Edynburg & 7,60 & 1793 & $\mathrm{k}$ & & $D$ \\
\hline Minshulls & Londyn & 4,60 & ok. 1810 & $\mathrm{k}$ & & I.11 \\
\hline \multirow{2}{*}{ James Manning } & \multirow{2}{*}{ Londyn } & 4,50 & k. XIX & e & & 1.8 \\
\hline & & 4,50 & k. XIX & $\mathrm{p}$ & & 1.9 \\
\hline Herman Moll & Londyn & 7,00 & 1719 & $\mathrm{k}$ & & $D$ \\
\hline Francois de Mongenet & Vesoul & 8,70 & $1560-1570$ & $\mathrm{t}, \mathrm{pr}$ & tylko mapa & $\mathrm{K}$ \\
\hline $\begin{array}{l}\text { Francois de Mongenet; } \\
\text { Heinrich Gebhard }\end{array}$ & Strasburg & 4,80 & pocz. XVII & z & & $\mathrm{K}$ \\
\hline Joseph Moxon & Londyn & 6,75 & ok. 1670 & $\mathrm{k}$ & $\begin{array}{l}\text { wersja } \\
\text { anglojęzyczna } \\
1 \text { szt, łacińska } \\
2 \text { szt. }\end{array}$ & $\mathrm{K}, \mathrm{K} 1$ \\
\hline Newton \& sons & Londyn & 3,75 & XIX & e & & 1.4 \\
\hline \multirow{7}{*}{ Newton Family } & \multirow{7}{*}{ Londyn } & 3,75 & ok. 1850 & $\mathrm{i}$ & & $\mathrm{D}, \mathrm{K}$ \\
\hline & & 6,50 & ok. 1875 & $\mathrm{i}$ & & $D$ \\
\hline & & 7,60 & 1816 & $\mathrm{k}$ & $\begin{array}{l}\text { bez mapy } \\
\text { nieba, } \\
\text { informacje } \\
\text { astronomicz- } \\
\text { ne, h }\end{array}$ & $D$ \\
\hline & & 7,60 & po 1833 & $\mathrm{t}$ & & D \\
\hline & & 7,60 & ok. 1860 & $\mathrm{t}$ & & $D$ \\
\hline & & 7,60 & 1830 & $\mathrm{k}$ & & $D$ \\
\hline & & 7,70 & 1817 & $\mathrm{k}$ & & $\mathrm{D}, \mathrm{K}$ \\
\hline $\begin{array}{l}\text { William i Newton John } \\
\text { Palmer }\end{array}$ & Londyn & 7,00 & 1783 & $\mathrm{k}$ & & $D$ \\
\hline Thomas Patrick & Londyn & 7,60 & 1808 & $\mathrm{k}$ & & $D$ \\
\hline \multirow{2}{*}{ Jean Pigeon } & \multirow{2}{*}{ Paryż } & 7,00 & 1717 & $\mathrm{t}$ & & $\mathrm{T}$ \\
\hline & & 7,00 & 1717 & $\mathrm{t}$ & $m$, srebrny, $f$ & $\mathrm{~K}$ \\
\hline $\begin{array}{l}\text { Charles Price } \\
\text { i John Senex }\end{array}$ & Londyn & 7,00 & ok. 1710 & $\mathrm{k}$ & & $D, D G$ \\
\hline
\end{tabular}




\begin{tabular}{|c|c|c|c|c|c|c|}
\hline Wytwórca & Miejscowość & Średnica [cm] & Data powstania & $\begin{array}{l}\text { Rodzaj } \\
\text { globusa }\end{array}$ & Uwagi & Źródło \\
\hline \multirow{3}{*}{ John Senex } & \multirow{3}{*}{ Londyn } & 7,00 & ok. 1750 & $\mathrm{t}, \mathrm{pr}$ & & $D$ \\
\hline & & 7,00 & pocz. XVIII & $\mathrm{i}$ & & $\mathrm{K}$ \\
\hline & & 7,00 & ok. 1740 & $\mathrm{k}$ & & $\mathrm{I} .12$ \\
\hline \multirow{2}{*}{ Pieter Maasz Smit } & \multirow{2}{*}{ Amsterdam } & 5,80 & 1698 & $\mathrm{t}$ & $\mathrm{h}$ & $\mathrm{K}$ \\
\hline & & 5,80 & pocz. XVIII & $\mathrm{t}$ & $\mathrm{h}$ & $\mathrm{K}$ \\
\hline \multirow[b]{2}{*}{ Charles Smith \& Son } & \multirow[b]{2}{*}{ Amsterdam } & 9,60 & 1834 & $\mathrm{k}$ & 1 & $D$ \\
\hline & & 6,50 & $\mathrm{XIX}$ & $\mathrm{k}$ & $\begin{array}{l}\text { zdekompleto- } \\
\text { wany bez etui }\end{array}$ & 1.5 \\
\hline Edward Stanford & Londyn & 5,00 & 1862 & $\mathrm{t}, \mathrm{pr}$ & & $D$ \\
\hline \multirow{4}{*}{ Gerard i Leonard Valk } & \multirow{4}{*}{ Amsterdam } & 7,75 & $1707-1728$ & $\mathrm{t}, \mathrm{pr}$ & & $\mathrm{K}$ \\
\hline & & 7,75 & $1707-1728$ & k & & $\mathrm{K}$ \\
\hline & & 7,75 & ok. 1725 & $\mathrm{t}, \mathrm{pr}$ & & $D$ \\
\hline & & 7,75 & ok. 1725 & $\mathrm{i}$ & & $D$ \\
\hline West of Soho Square & Londyn & 7,00 & ok. 1815 & $\mathrm{k}$ & & $D$ \\
\hline $\begin{array}{l}\text { Gilles and Didier Robert } \\
\text { de Vaugondy }\end{array}$ & Paryż & 8,50 & 1745 & $\mathrm{p}$ & & 1.6 \\
\hline Charles Whitwell & Londyn & 6,20 & ok. 1590 & $\mathrm{t}, \mathrm{pr}$ & m, srebrny & $D$ \\
\hline James Wyld Jr. & Londyn & 8,30 & $1839 / 1840$ & pt & & DG \\
\hline
\end{tabular}

Rodzaj globusa: $\mathrm{d}$ - podstawa drewniana; e - etui drewniane; ed - etui drewniane z mapą nieba oklejoną na po stronie zewnętrznej; ebn - etui drewniane bez nieba; $f$ z południkiem; $\mathrm{h}$ - z płytą horyzontu; $\mathrm{i}$ - część przyrządu typu tellurium lub planetarium; $\mathrm{k}$ - kieszonkowy; I - łączenie na południku; $\mathrm{m}$ - rękopiśmienny; $\mathrm{n}$ - globus nieba; $\mathrm{p}$ - pudetko tekturowe; $\mathrm{pr}$ - para; $\mathrm{s}$ - skrzynka (pudełko) drewniana; $\mathrm{t}$ - tradycyjny; $\mathrm{z}$ - zegar.

\section{Źródła}

K - P. van der Krogt, Old globes in the Netherlands. A catalogue of terrestrial and celestial globes made prior to 1850 and preserved in Dutch collections, Utrecht 1984.

K1 - P. van der Krogt, Globes. Made Portable for the Pocket, „Bulletin of the Scientific Instrument Society”, 7, 1985.

D -E. Dekker, Globes at Greenwich. A catalogue of the globes and armillary spheres in the National Martime Museum, Oxford 1999.

DG - E. Dahl, J.-F. Gauvin, Sphaerae Mundi, Montreal 2000.

S - S. Sumira, Globes: 400 Years of Exploration, Navigation, and Power, Chicago 2014.

T - M. Taborska, Antique globes in Poland, 1480-1860. A new inventory, „Journal of the International Map Collectors' Society”, 161, 2020, s. 26.

$\mathrm{V}$ - Österreichische Nationalbobliothek, baza danych (https://www.onb.ac.at/en/museums/globe-museum, dostęp: 5 stycznia 2021).

I - Christie's. A Dutch $21 / 2$-inch pocket globe, Johannes Deur, circa 1720. Live Auction 8668: Travel, Science and Natural History 2013 (https://www.christies.com/en/lot/ lot-5672833, dostęp: 20 grudnia 2020).

I.1. DeRoo Antiquariaat. New and Correct Globe with the Trade Winds and Monsoons, 2021 (https://deroorarebooks.com/product/new-and-correct-globe-with-the-trade-windsand-monsoons/, dostęp: 7 stycznia 2021).

I.2. Selling Antiques, Nr aukcji SA754346 (https://www.sellingantiques.co.uk/754346/fine-18th-century-english-celestial-pocket-globe-by-nathaniel-hill-london-1754/, dostęp: 7 stycznia 2021).

I.3 George Glazer Gallery, Globe, miniature, terrestial pocket globe in iron stand, antique, Nicolas Lane, London, 1809 (https://www.georgeglazer.com/wpmain/product/globeminiature-terrestrial-pocket-globe-on-iron-stand-antique-nicolas-lane-london-1809/, dostęp: 6 stycznia 2021).

I.4. Selling Antiques, Nr aukcji SA749409 (https://www.sellingantiques.co.uk/749409/rare-newton-sons-15-inch-miniature-globe/, dostęp: 8 stycznia 2021).

1.5. Selling Antiques, Nr aukcji SA747609 (https://www.sellingantiques.co.uk/747609/19th-century-smith-son-london-25-inch-globe/, dostęp: 8 stycznia 2021).

I.6. Stanfords est, Nr aukcji 0781934502494 (https://www.stanfords.co.uk/vaugondy-globe-1745-small_0781934502494, dostęp: 6 stycznia 2021).

I.7. Antique Maps, Globes, Books \& Prints by Murray Hudson, Nr aukcji G-10367 (https://antiquemapsandglobes.com/Globe/Antique/Rare-American-Holbrook-Hinged-SchoolGlobe?G=10367, dostęp: 5 stycznia 2021).

I.8. Science Museum Group Collection. Miniature terrestrial globe by J. Manning. Late 19, 1991 (https://collection.sciencemuseumgroup.org.uk/objects/c057241/miniatureterrestrial-globe-by-j-manning-late-19-terrestrial-globe, dostęp: 14 stycznia 2021).

1.9. Chrisite's. A 1 3/4 -inch miniature terrestrial globe, 2014 (https://www.christies.com/en/lot/lot-5782948, dostęp: 5 stycznia 2021). 
I.10. Christie's. An English 3-inch pocket globe, 2018 (https://www.christies.com/lot/lot-an-english-3-inch-pocket-globe-rb-bate-6181845/?from=searchr esults\&int0bjectID=6181845, dostęp: 16 grudnia 2020).

I.11. Christie's. An English 3-inch pocket globe, 2016 (https://onlineonly.christies.com/s/mapping-globe/english-3-inch-pocket-globe-52/35320, dostęp: 18 grudnia 2020).

I.12. Christie's. A 23/4-inch terrestrial pocket globe, 2009 (https://www.christies.com/lot/lot-a-2-inch-terrestrial-pocket-globe-i-senex-5219468/?from=sea rchresults\&int0bjectID=5219468, dostęp: 16 grudnia 2020).

I.13. Christie's. An English 3-inch pocket globe, 2016 (https://onlineonly.christies.com/s/mapping-globe/english-3-inch-pocket-globe-57/35325, dostęp: 16 grudnia 2020).

I.14. Christie's. An English 3-inch pocket globe 2011 (https://www.christies.com/lot/lot-an-english-3-inch-pocket-globe-t-harris-5421513/?from=searchr esults\&int0bjectID=5421513, dostęp: 14 stycznia 2021).

Tabela 2. Wykaz gwiazdozbiorów

\begin{tabular}{|c|c|c|c|}
\hline Gwiazdozbiór & Na globusie Deura (mapie Heweliusza) & Odkrywca & Obecnie w gwiazdozbiorze \\
\hline Andromeda & Andromeda & $\mathrm{P}$ & \\
\hline Antoniusz & Antonious & $P$ & Orła \\
\hline Rajski Ptak & Apus & K & \\
\hline Wodnik & Aquarius & $\mathrm{P}$ & \\
\hline Orzeł & Aquilla & $\mathrm{P}$ & \\
\hline Ołtarz & Ara & $P$ & \\
\hline Baran & Aries & $P$ & \\
\hline Okręt Argo & Argo Navis & $\mathrm{P}$ & Kil, Rufa, Żagiel \\
\hline Woźnica & Auriga & $\mathrm{P}$ & \\
\hline Psy Gończe 2 & Asterion & $\mathrm{H}$ & \\
\hline Wolarz & Boötes & $P$ & \\
\hline Żyrafa & Camelopardalus (Camelopardalis) & B & \\
\hline Rak & Cancer & $\mathrm{P}$ & \\
\hline Wielki Pies & Canis Maior & $\mathrm{P}$ & \\
\hline Mały Pies & Canis Minor & $P$ & \\
\hline Psy Gończe & (Canes Venatici) & $\mathrm{H}$ & \\
\hline Koziorożec & Capricornus & $P$ & \\
\hline Kasiopea & Cassiopeia & $P$ & \\
\hline Centaur & Centaurius & $P$ & \\
\hline Cefeusz & Cepheus & $P$ & \\
\hline Cerber & Cerberus & $\mathrm{H}$ & Herkules \\
\hline Wieloryb & Cetus & $P$ & \\
\hline Kameleon & Chameleon & K & \\
\hline Psy Gończe 1 & Chara & $\mathrm{H}$ & \\
\hline Gołąb & Colomba & PP & \\
\hline Warkocz Bereniki & Coma Berenices & $\mathrm{T}$ & \\
\hline Korona Południowa & Corona Australis & $P$ & \\
\hline Korona Północy & Corona Borealis (Corona) & $P$ & \\
\hline Kruk & Corvuus & $P$ & \\
\hline
\end{tabular}




\begin{tabular}{|c|c|c|c|}
\hline Gwiazdozbiór & Na globusie Deura (mapie Heweliusza) & Odkrywca & Obecnie w gwiazdozbiorze \\
\hline Puchar & Crater & $\mathrm{P}$ & \\
\hline Krzyż Południa & Crux & $\mathrm{P}$ & \\
\hline Łabędź & Cygnus & $\mathrm{P}$ & \\
\hline Delfin & Delphinus & $\mathrm{P}$ & \\
\hline Złota Ryba & Dorado & $\mathrm{K}$ & \\
\hline Smok & Draco & $\mathrm{P}$ & \\
\hline Źrebię & Equuleus & $\mathrm{P}$ & \\
\hline Erydan & Erydann & $\mathrm{P}$ & \\
\hline Bliźnięta & Gemini & $\mathrm{P}$ & \\
\hline Żuraw & Grus & $\mathrm{K}$ & \\
\hline Herkules & Hercules & $\mathrm{P}$ & \\
\hline Hydra & Hydra & $\mathrm{P}$ & \\
\hline Wąż Wodny & Hydrus & $\mathrm{K}$ & \\
\hline Indianin & Indus & $\mathrm{K}$ & \\
\hline Jaszczurka & Lacerta & $\mathrm{H}$ & \\
\hline Lew & Leo & $\mathrm{P}$ & \\
\hline Mały Lew & Leo Minor & $\mathrm{H}$ & \\
\hline Zając & Lepus & $\mathrm{P}$ & \\
\hline Waga & Libra & $P$ & \\
\hline Wilk & Lupus & $P$ & \\
\hline Ryś & Lynx (Lynx sive Tigris) & $\mathrm{H}$ & \\
\hline Lutnia & Lyra & $P$ & \\
\hline Jednorożec & Monoceros & B & \\
\hline Góra Menalus & Mons Menalus (Mons Maenalis) & $\mathrm{H}$ & Wolarz \\
\hline Mucha Południowa & Musca [Australis] & $\mathrm{K}$ & \\
\hline Mucha Północna & Musca [borealis] & PP & - \\
\hline Orion & Orion & $\mathrm{P}$ & \\
\hline Paw & Pavo & $\mathrm{K}$ & \\
\hline Pegaz & Pegasus & $\mathrm{P}$ & \\
\hline Perseusz & Perseus & $\mathrm{P}$ & \\
\hline Feniks & Phoenix & $\mathrm{K}$ & \\
\hline Ryby & Pisces & $P$ & \\
\hline Ryba Południowa & Piscis [...] (Piscis Volans) & $\mathrm{P}$ & \\
\hline Dąb Karola & Robus Caroli & $\mathrm{HI}$ & Kil i Żagiel \\
\hline Strzała & Sagitta & $\mathrm{P}$ & \\
\hline Strzelec & Sagittarius & $\mathrm{P}$ & \\
\hline Skorpion & Scorpius & $\mathrm{P}$ & \\
\hline
\end{tabular}




\begin{tabular}{|l|l|c|c|}
\hline Gwiazdozbiór & Na globusie Deura (mapie Heweliusza) & Odkrywca & Obecnie w gwiazdozbiorze \\
\hline Tarcza Sobieskiego & Scutum Sobiescianum & $\mathrm{H}$ & \\
\hline Wąż & Serpens & $\mathrm{P}$ & \\
\hline Wężownik & Serpentarius & $\mathrm{P}$ & \\
\hline Sekstant & Sextans Uraniae & $\mathrm{H}$ & \\
\hline Byk & Taurus & $\mathrm{P}$ & \\
\hline Trójkąt & Triangulum Maius (Triangulum) & $\mathrm{H}$ & \\
\hline Trójkąt Mały & Triangulum Minus & $\mathrm{K}$ & \\
\hline Trójkąt Południa & Trinag. Austral & $\mathrm{K}$ & \\
\hline Tukan & Tucana (Toucan) & $\mathrm{P}$ & \\
\hline Wielka Niedźwiedzica & Ursa Maior & $\mathrm{P}$ & \\
\hline Mała Niedźwiedzica & Ursa Minor & $\mathrm{P}$ & \\
\hline Panna & Virgo & $\mathrm{K}$ & \\
\hline Ryba latająca & Volantis (Piscis Volans) & $\mathrm{H}$ & \\
\hline Lisek & Vulpecula (Vulpecula cum Anser) & \\
\hline
\end{tabular}

Legenda: H - Heweliusz, K - Keyser i de Houtman; P - Ptolemeusz; HI - Halley; PP - Petrus Placius; B - Bartsch; T - Tycho Brahe.

\section{Bibliografia}

\section{Źródła}

Scherer H., Atlas Novus, Monachium 1702-1710. van der Aa A.J., Biographisch Woordenboek der Nederlanden, t. 4, Haarlem 1858.

van der Aa P., Scheeps-Togt door Ferdinand Magellaan uit Kastilien gedaan na $R$. de laPlata en van daar

\section{Literatura}

Bryden D.J., Early Printed Ephemera of London Instrument Makers. Trade Catalogues. Part. I: Joseph Moxon, 1673, „Bulletin of the Scientific Instrument Society", 64, 2000, s. 13-16.

Dekker E., Globes at Greenwich. A catalogue of the globes and armillary spheres in the National Martime Museum, Oxford 1999.

Dekker E., Pocket globe, w: The History of Cartography, t. 4: Cartography in the European Enlightenment, ed. M.H. Edney, M.S. Pedly, Chicago 2020, s. $573-575$.

Dobrowolski P., Watch your pocket - krótka historia zamożności, czyli kradzieże zegarków $w$ Londynie $w$ XVIII $w$., „Kwartalnik Historii Kultury Materialnej”, 63 (3), 2015, s. 451-470.

Edell S., Concave hemispheres of the starry orb., „Bulletin of the Scientific Instrument Society”, 7, 1985, s. 6-8. door zyn Ontdekte Straat tot aan de Moluccas, Amsterdam 1707.

van der Aa P., T Noorder Deel Van Amerika door C. Kolumbus, Amstedam 1707.

Heweliusz J., Prodromus astronomiae cum catalogo fixarum et firmamentum Sobiescianum, Gdańsk 1690.

Jaillot H., Sanson N., Atlas Nouveau, 1692-1993, (https://pl.wikipedia.org/wiki/Plik:1691_Sanson_Map_of_the_World_on_Hemisphere_Projection_-_Geographicus_-_World2-sanson-1691. jpg, dotęp: 5 stycznia 2021).

Morpurgo E., Nederlandse klokken-en horlogemakers vanaf 1300, Amsterdam 1970.

Muller F., Index of Globes and Globe Makers, w: Catalogue de Geographie, Cartographie, Voyages, No. 93. Amsterdam 1891, s. 10-12.

Olszewicz B., Alte Globen in Polen, „Der Globusfreund", 15/16, 1966/1967, s. 263-277.

Stevenson E.L., Terrestial nad celestial globes..., t. 2, Londyn 1921.

Sumira S., Globes: 400 Years of Exploration, Navigation, and Power, Chicago 2014. 
Taborska M., Antique globes in Poland, 1480-1860. A new inventory, ,Journal of the International Map Collectors' Society", 161, 2020, s. 18-30.

van der Krogt P., Globes. Made Portable for the Pocket, „Bulletin of the Scientific Instrument Society”, 7, 1985, s. 8-15.

van der Krogt P., Globi Neerlandici. The production of globes in the Low Countries, Utrecht 1993.

van der Krogt P., Old globes in the Netherlands. A catalogue of terrestrial and celestial globes made prior to 1850 and preserved in Dutch collections, Utrecht 1984.

Wallis H., Robinson A.H., Cartographical Innovations. An International Handbook of Mapping Terms to 1900, Tring, Hertfordshire 1987.

Webster R.S., Webster M.K., Signature Database, Adler Planetarium, (http://www.adlerplanetarium.org, dostęp: 6 stycznia 2021).

\section{The miniature globe of Johannes Deur in the Jagiellonian University Museum}

\section{Summary}

The pocket globe made in Amsterdam by Johannes Deur (1667-1734) belongs to the most valuable antique globes. It is one of the three currently known works of Deur. The object consists of two elements: the first is a wooden orb with a diameter of $6 \mathrm{~cm}$ and a terrestrial map glued to it, and the second is a paperboard case with a celestial map (Fig. 1). It belongs to the group of miniature globes characterised by a diameter no larger than $10 \mathrm{~cm}$. The subject is specified by a listing of miniature globes and their manufacturers presented in Table 1 .

Most scholars date the globe to c. 1720 . The object in question was a part of the first edition, and map details make it possible to place the time of its creation between 1699 and 1707 .

Deur's globe is distinguished by the method of dividing the celestial map - along the meridian instead of the equator (Fig. 3). The only other pocket globes using the same manner were produced by the company of Charles Smith
\& Son (Amsterdam, 1834) and T. Harris \& Son (London, early nineteenth century).

Early pocket globes made in the seventeenth and eighteenth centuries were expensive and visually impressive objects made for rich people as precious novelties. Eventually, globe manufacturing became more affordable due to the development of printing techniques, and miniature globes became a popular teaching aid.

The map analysis revealed that the iconography of star constellations is based on the images developed by Johannes Hevelius for his treatise entitled Prodromus Astronomia released in 1690 (Gdańsk/Danzig). The list of constellations is in Table 2. The map of Earth depicts the world as it was known in the early eighteenth century. The map features several details related to legendary locations (e.g. the Strait of Anian; Figs 2 and 6). Additionally, numerous elements refer to cartographic mysteries of the period.

Małgorzata Taborska - biolog, geodeta i muzealnik. Od 2004 r. opiekun zbiorów instrumentów naukowych w Muzeum Uniwersytetu Jagiellońskiego. Zajmuje się szczególnie globusami, zegarami, przyrządami meteorologicznymi, geodezyjnymi oraz wyposażeniem laboratoriów biologicznych. Główne zainteresowania badawcze: historia nauki przez pryzmat rozwoju instrumentów naukowych, globusy (malgorzata.taborska@uj.edu.pl)

Małgorzata Taborska - biologist, geodesist, and museologist. Since 2004, she has been a custodian of scientific instruments at the Jagiellonian University Museum. Her research focuses on globes, clocks, meteorological and geodetic instruments, and biological laboratory equipment. Her primary research interests cover: history of science in the context of the development of scientific instruments, globes (malgorzata.taborska@uj.edu.pl) 